\title{
Study of the anticorrosive properties of magnetic composites
}

\section{Estudio de las propiedades anticorrosivas de compositos magnéticos}

\author{
MARTINEZ-MORENO, Miguel†, GÁMEZ-DUEÑAS, Claudia L., FUENTES-RAMÍREZ, Rosalba \\ and CONTRERAS-LOPEZ, David*
}

Universidad de Guanajuato, Division of Natural and Exact Sciences, Department of Chemical Engineering, Noria Alta $S$ / N, Noria Alta, 36050, Guanajuato, Guanajuato, Mexico.

ID $1^{\text {st }}$ Author: Miguel, Martinez-Moreno / ORC ID: 0000-0002-0992-8505, CVU CONACYT ID: 958747

ID $1^{\text {st }}$ Coauthor: Claudia L., Gámez-Dueñas / ORC ID: 0000-0002-8126-6518

ID $2^{\text {nd }}$ Coauthor: Rosalba, Fuentes-Ramírez / ORC ID: 0000-0003-0520-3387, CVU CONACYT ID: 202669

ID $3^{\text {rd }}$ Coauthor: David, Contreras-Lopez / ORC ID: 0000-0003-1384-4766, CVU CONACYT ID: 38297

DOI: $10.35429 /$ JTI.2020.20.7.13.18

Received January 20, 2020; Accepted June 30, 2020

\begin{abstract}
Metal corrosion affects various sectors: construction, ships, pipes in the chemical industry, etc. Organic materials have been used as coatings to counteract it; recently improvements have been observed when magnetic polymers are used. These are materials formed by a polymeric matrix and a metal with magnetic properties, such as magnetic nanoparticles. The metal is sacrificed, preventing contact with the surface. Here we show the results of composites formed by magnetic nanoparticles of cobalt ferrite and magnetite obtained by coprecipitation, immersed in polystyrene, butyl polyacrylate and styrene-butyl acrylate copolymer matrices. The nanoparticles were incorporated by ultrasonic bath using different weights of nanoparticles $(0.05 \%, 0.25 \%, 0.5 \%$ and $1 \%)$ using toluene as solvent. There is an acceptable dispersion of the nanoparticles in the polyacrylate and copolymer after 4 hours of cavitation, the styrene had acceptable dispersion after 5 hours. The composites were tested on a $316 \mathrm{Cal} .14$ stainless steel film of $6 \mathrm{~cm} 2$ area, the specimens were dipped in acid to evaluate the corrosion protection with electrochemical techniques, having good results in the ferrite and magnetite composites where the protection capacity was better in the styrene-butyl acrylate copolymer.
\end{abstract}

Magnetic nanoparticles, Magnetic polymers, Corrosion inhibitors

\begin{abstract}
Resumen
La corrosión de metales afecta diversos sectores: construcciones, embarcaciones, tuberías en la industria química, etc. Los materiales orgánicos han sido empleados como recubrimientos para contrarrestarla; últimamente se han observado mejoras cuando se usan polímeros magnéticos. Estos son materiales formados por una matriz polimérica y un metal con propiedades magnéticas, como las nanopartículas magnéticas. El metal se sacrifica, impidiendo el contacto con la superficie. Aquí se muestran los resultados de compositos formados por nanopartículas magnéticas de ferrita de cobalto y magnetita obtenidas por coprecipitación, inmersas en matrices de poliestireno, poliacrilato de butilo y copolímero estireno-acrilato de butilo. Las nanopartículas se incorporaron mediante baño ultrasónico usando diferentes pesos de nanopartícula $(0.05 \%, 0.25 \%, 0.5 \%$ y $1 \%)$ usando tolueno como disolvente. Hay una dispersión aceptable de las nanopartículas en el poliacrilato y copolímero después de 4 horas de cavitación, el estireno tuvo dispersión aceptable después de 5 horas. Se probaron los compositos en una película de acero inoxidable $316 \mathrm{Cal}$. 14 de área $6 \mathrm{~cm} 2$, las probetas se sumergieron en ácido para evaluar la protección ante la corrosión con técnicas electroquímicas, teniendo buenos resultados en los compositos de ferrita y magnetita donde la capacidad de protección mejor fue en el copolímero estireno-acrilato de butilo.
\end{abstract}

Nanopartículas magnéticas, Polímeros magnéticos, Inhibidores de corrosión

Citation: MARTINEZ-MORENO, Miguel, GÁMEZ-DUEÑAS, Claudia L., FUENTES-RAMÍREZ, Rosalba and CONTRERAS-LOPEZ, David. Study of the anticorrosive properties of magnetic composites. Journal of Technology and Innovation. 2020. 7-20:13-18.

\footnotetext{
* Correspondence to Author (E-Mail: david.contreras@ugto.mx)

$\dagger$ Researcher contributing as first author.
} 


\section{Introduction}

Organic compounds are effective inhibitors of aqueous corrosion of many metals and alloys. The search for new and efficient corrosion inhibitors requires the study between the dependence of the protection efficiency on the size of the inhibitor molecule and the distribution in the inhibitor molecule in the composite. [1,3,5,6,8]. Magnetite belongs to class spinel ferrites, which have crystal lattice noble spinel $\mathrm{MgAl}_{2} \mathrm{O}_{4}$ [1] of the general formula MeFe2O4. Many uses of magnetite nanoparticles due to its special physical and chemical properties. Magnetic nanoparticles can be prepared by different methods and embedding into the polymer solution [9]. This method is very flexible since it allows for the preparation of magnetite nanoparticles carrying a wide variety of stabilizers including copolymers, surfactants, and mixtures of them. However, polymer nanomaterials provide a variety of advantages over other materials because they have a wide range of source materials and tunable surface functionalities [7].

The superparamagnetic $\mathrm{Fe}_{3} \mathrm{O}_{4}$ and ferrite nanoparticles coated with polymers are usually composed of the magnetic cores to ensure a strong magnetic response and a polymeric shell to provide favorable functional groups and features [4]. The magnetic nanoparticles, which possesses strong magnetic property and superparamagnetic behavior, is of relatively low toxicity to the human body when encapsulated in the protective polymer shell, which is crosslinked polymer composites.

The polymer prevents the magnetic from oxidation and aggregation. In this respect, it was expected that the using of nanoparticles in the field of corrosion inhibition protection for steel instead of normal organic inhibitors can produce uniform thin film (without any pine hole due to cross-linked polymers) on the surface of steel to cover all surface without any defects which provide advantages over.

\section{Methodology}

The synthesis of the polymers was via free radicals (FRP). The reaction carried out at $80{ }^{\circ} \mathrm{C}$ and magnetic agitation at $600 \mathrm{rpm}$ for $3 \mathrm{~h}$. The emulsion was broken using $\mathrm{NaCl}$ to recover the polymer and washed with toluene and methanol, then left to dry for two days at $60-70{ }^{\circ} \mathrm{C}$.
The copolymer was made with the same methodology using a 50:50 mass percentage of styrene and butyl acrylate.

The nanoparticles were synthesized by the (co)precipitation method. The cobalt ferrite was obtained using $0.2 \mathrm{M} \mathrm{KOH}$ as dispersing agent with $0.1 \mathrm{M} \mathrm{FeCl}_{3}$ and $0.5 \mathrm{M} \mathrm{CoCl}_{2}$ as metal precursor solutions, added by dripping into the $\mathrm{KOH}$ solution at $60{ }^{\circ} \mathrm{C}$ and $250 \mathrm{rpm}$, after dripping it was left to magnetic stir for $30 \mathrm{~min}$. The nanoparticles were recovered using water washings and finally a methanol wash, then the sample was decanted and left to dry for a day at $70-80{ }^{\circ} \mathrm{C}$. Magnetite was made using the same method but replacing $\mathrm{CoCl}_{2}$ with $0.5 \mathrm{M} \mathrm{FeCl}_{2}$.

The nanoparticles were incorporated into the polymeric matrix by means of an ultrasonic bath at a temperature between $18-30^{\circ} \mathrm{C}$. For each sample, $0.2 \mathrm{~g}$ of polymer was fixed and the percentage of the nanoparticle $(0.05,0.25,0.5$, $1 \%$ ) in weight of the polymer was varied using toluene as the solvent medium. The dispersion of the nanoparticles at different times $(0.5,1$ and 4 h) was analyzed to know the stability of the matrix. The nanocomposites were placed in conductive glasses and a cyclic voltammetry was performed on each composite from -1.5 to $1.5 \mathrm{~V}, 2$ cycles at $50 \mathrm{mV} / \mathrm{s}$ in $\mathrm{Na}_{2} \mathrm{~S}_{2} \mathrm{O}_{3} \quad 1 \mathrm{M}$. The nanocomposite was placed in stainless steel sheet of $316 \mathrm{Cal} .14$ and subjected to $\mathrm{H}_{2} \mathrm{SO}_{4} 0.5 \mathrm{M}$ for $30 \mathrm{~min}$ to determine the resistance of the material to aggressive media. Impedance spectroscopy was performed with a potentiostat SP-150 Biologic Science Instruments with Software Ec-Lab V10.19 and a three-electrode cell at room temperature, as a reference electrode $(0.1 \mathrm{M} \mathrm{KCl}$ solution), as a counter electrode a platinum wire, in $1 \mathrm{M} \mathrm{H}_{2} \mathrm{SO}_{4}$ acid medium. Under conditions of 20000 to $0.1 \mathrm{~Hz}$ frequency, 10 points, and a voltage range of $-10 \mathrm{~V}: 10$ V.

\section{Results}

Figures 1, 2 and 3 show the infrared spectrum of polystyrene, butyl polyacrylate and S-AB copolymer respectively. In the case of polystyrene, band of an aromatic monosubstituted is in region to $1940-1745 \mathrm{~cm}^{-1}$, bands of stretching $\mathrm{C}-\mathrm{H}$ bonds between 3080$3090 \mathrm{~cm}^{-1}$, bands of stretching $\mathrm{CH}_{2}$ bonds between $2920-2850 \mathrm{~cm}^{-1}$ and the band between 750 to $690 \mathrm{~cm}^{-1}$ corresponds to the monosubstitution of the ring. Perhaps, $1600 \mathrm{~cm}^{-1}$ correspond the bond $\mathrm{C}=\mathrm{C}$ and between 1490$1450 \mathrm{~cm}^{-1}$ the bond C-C. 


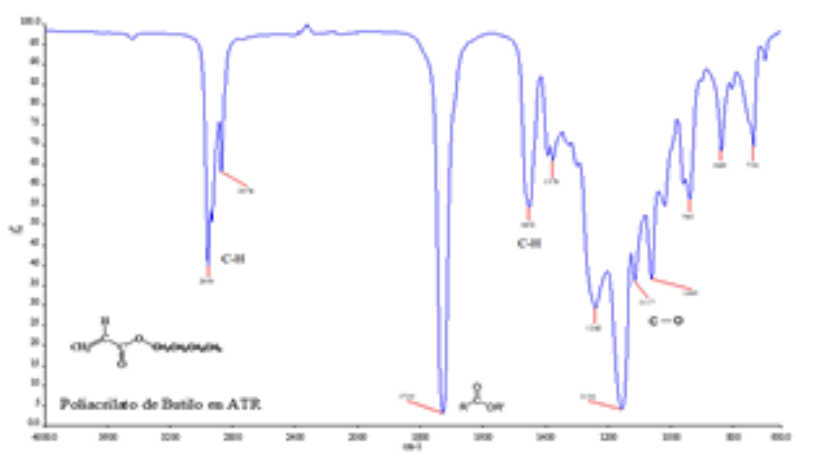

Figure 1 Infrared spectrum of polystyrene Source: own work [Origin Pro 9]

Figure 2 shows the bands of the $\mathrm{C}-\mathrm{H}$ bonds between 3000 to $2870 \mathrm{~cm}^{-1}$ band, at 1729 $\mathrm{cm}^{-1}$ due to the presence of carbonyl groups $\mathrm{C}=\mathrm{O}$ and between 1060-1120 $\mathrm{cm}^{-1}$ the C-O link. Figure 3 shows the linkage bands of the polystyrene and butyl polyacrylate structures are present.

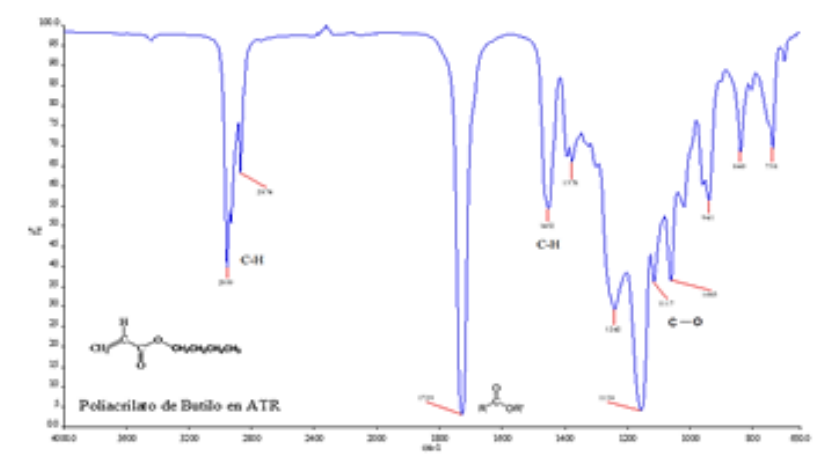

Figure 2 Infrared spectrum of butyl polyacrylate Source: own work [Origin Pro 9]

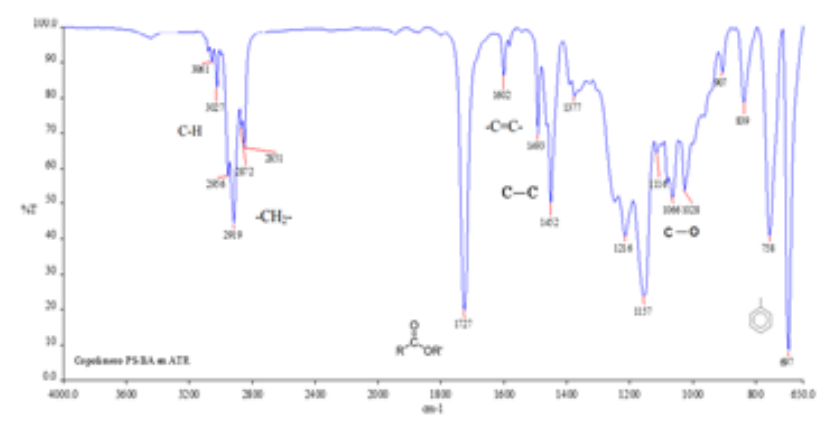

Figure 3 Infrared spectrum of S-AB copolymer Source: own work [Origin Pro 9]

As can be seen, the copolymer has the characteristic bands of its corresponding homopolymers, confirming the presence of polymeric matrices for the present study.

The micrographics to the Figure 4 and 5 showed the morphology and sizes of the nanoparticles of magnetite and cobalt ferrite respectively.

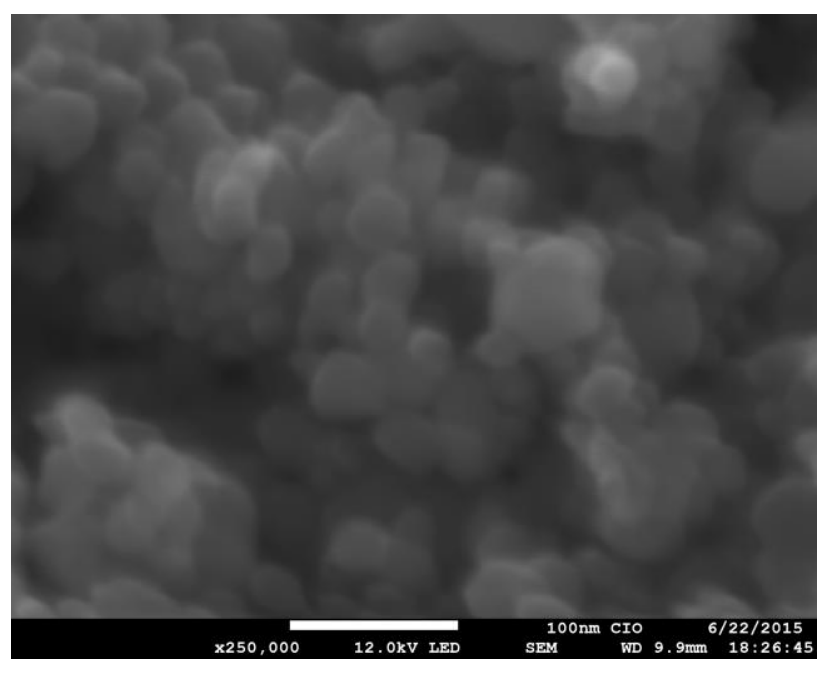

Figure 4 Magnetite micrograph

Source: own work [JEOL SU 3500 SEM Hitachi]

As can see been, in Figure $4 \mathrm{a}$ it is possible to observe an average particle size of 30 $\mathrm{nm}$, spherical shape and a small distribution. similarly, a slight agglomeration of the nanoparticles is observed due to the magnetic attraction $\mathrm{Fe}^{+2} / \mathrm{Fe}^{+3}$ atoms.

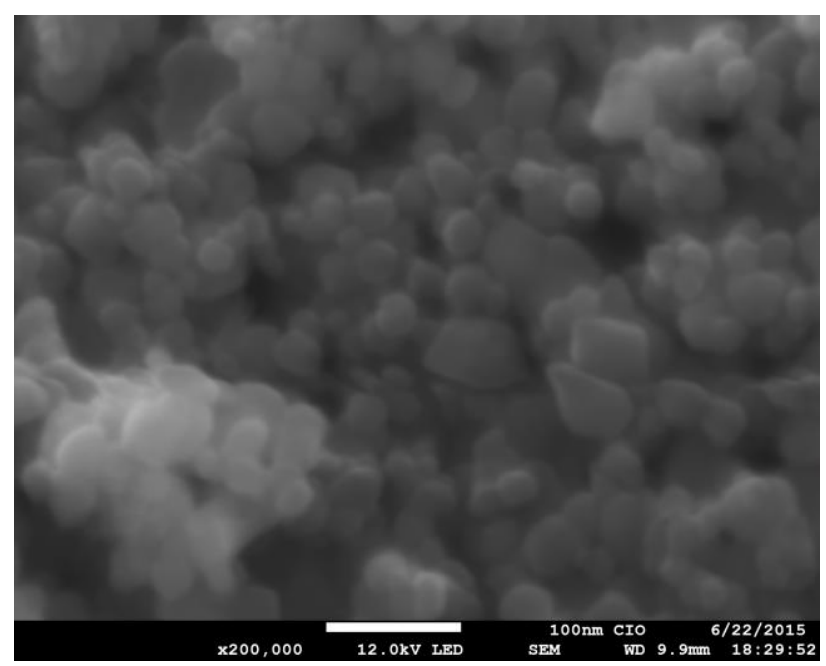

Figure 5 Cobalt ferrite micrograph Source: own work [JEOL SU 3500 SEM Hitachi]

The Figure 5 showed that the nanoparticles have an average particle size of 20 $\mathrm{nm}$ and have different shapes, with a agglomeration of the nanoparticles.

In spite of sonication times by ultrasonic bath showed that for 1 hour the NPs did not show good dispersion. After 4 hours, most of the blending were stable. This can be understood since the NP's are agglomerated by magnetic attraction, with the sonication time the energy separates the NP's avoiding the agglomerates, increasing the time the energy increases, having less drift, increasing the NP's available to distribute uniformly throughout the matrix. 
Before, the composite was placed on steel plaque and subjected to a sulfuric acid medium, Table 1 shows the weight loss when subjected to the acid medium.

\begin{tabular}{|l|l|l|l|l|}
\hline & $\begin{array}{c}\text { Weight } \\
\text { plaque only } \\
\text { polymeric } \\
\text { film [g] }\end{array}$ & $\begin{array}{c}\text { Weight } \\
\text { plaque } \\
\text { after acid } \\
\text { [g] }\end{array}$ & $\begin{array}{c}\text { lost } \\
\text { weight } \\
\text { [g] }\end{array}$ & $\begin{array}{c}\text { \% lost } \\
\text { weight }\end{array}$ \\
\hline $\begin{array}{l}\text { Ferrite- } \\
\text { Copolym. }\end{array}$ & & & & $\leq 0.129$ \\
\hline $0.05 \%$ & 13.4701 & 13.4530 & 0.0171 & 0.127 \\
\hline $0.25 \%$ & 15.6879 & 15.6712 & 0.0167 & 0.106 \\
\hline $0.50 \%$ & 14.3716 & 14.3532 & 0.0184 & 0.128 \\
\hline $1.00 \%$ & 14.0692 & 14.0564 & 0.0128 & 0.091 \\
\hline $\begin{array}{l}\text { Magnetite- } \\
\text { Copolym. }\end{array}$ & & & & $\leq 0.129$ \\
\hline $0.05 \%$ & 13.5932 & 13.5759 & 0.0173 & 0.127 \\
\hline $0.25 \%$ & 14.2136 & 14.2004 & 0.0132 & 0.093 \\
\hline $0.50 \%$ & 13.4820 & 13.4670 & 0.0150 & 0.111 \\
\hline $1.00 \%$ & 13.9677 & 13.9572 & 0.0105 & 0.075 \\
\hline
\end{tabular}

Table 1 Percentage weight loss due to corrosion in a $\mathrm{H}_{2} \mathrm{SO}_{4} 0.5 \mathrm{M}$

Source: own work [Word]

An uncoated steel plate was taken as a reference. It was obtained that weight should be lost in percentage of less than or equal to $0.129 \%$ (as can see been on the Table 1), only the steel plaque with the copolymer with both nanoparticles resulted in weight lost within the mentioned percentage.

In Figure 6a and Figure 6b, we can see the steel plaques coated with the samples of magnetic polymer after exposure in acidic medium. Where the PS and PBuA plaques showed greater wear, the coating was able to pass through and cause wear on the steel. In the case of the PBuA/PS copolymer composite, the complete coating was maintained without corrosion damage.

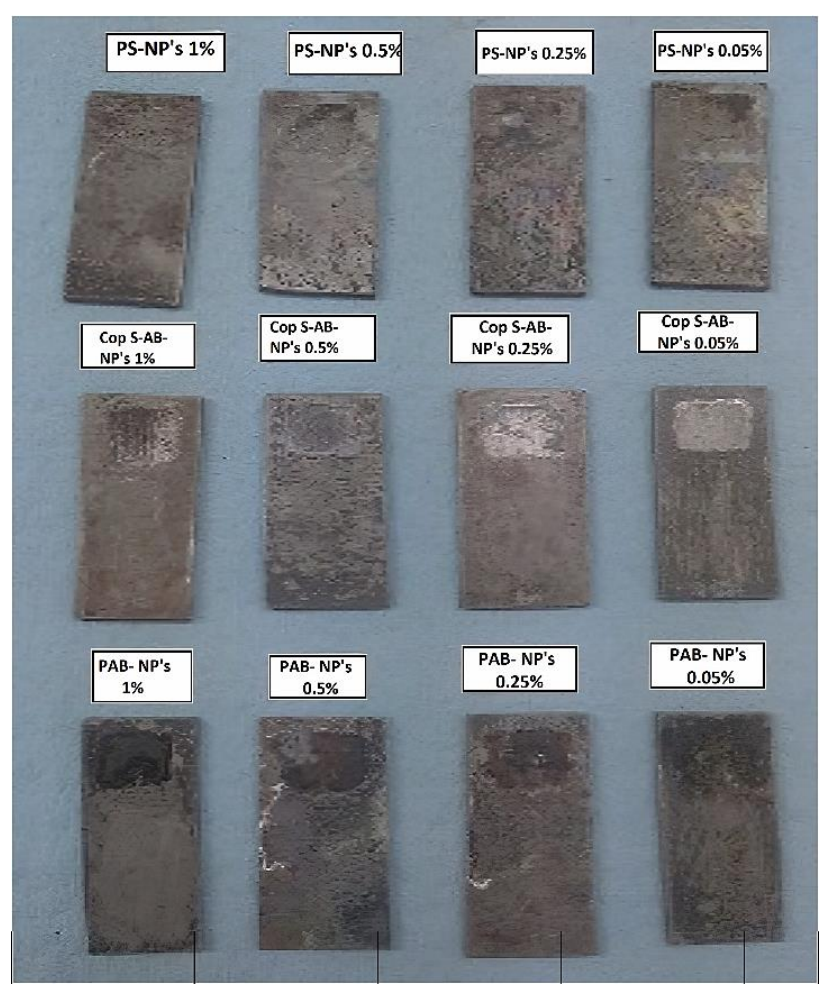

Figure 6 Nanocomposite films on metal plaques. Nanocomposite of Ferrite-PS, Ferrite-Copolym, Ferrite$\mathrm{PBuA}$

Source: own work

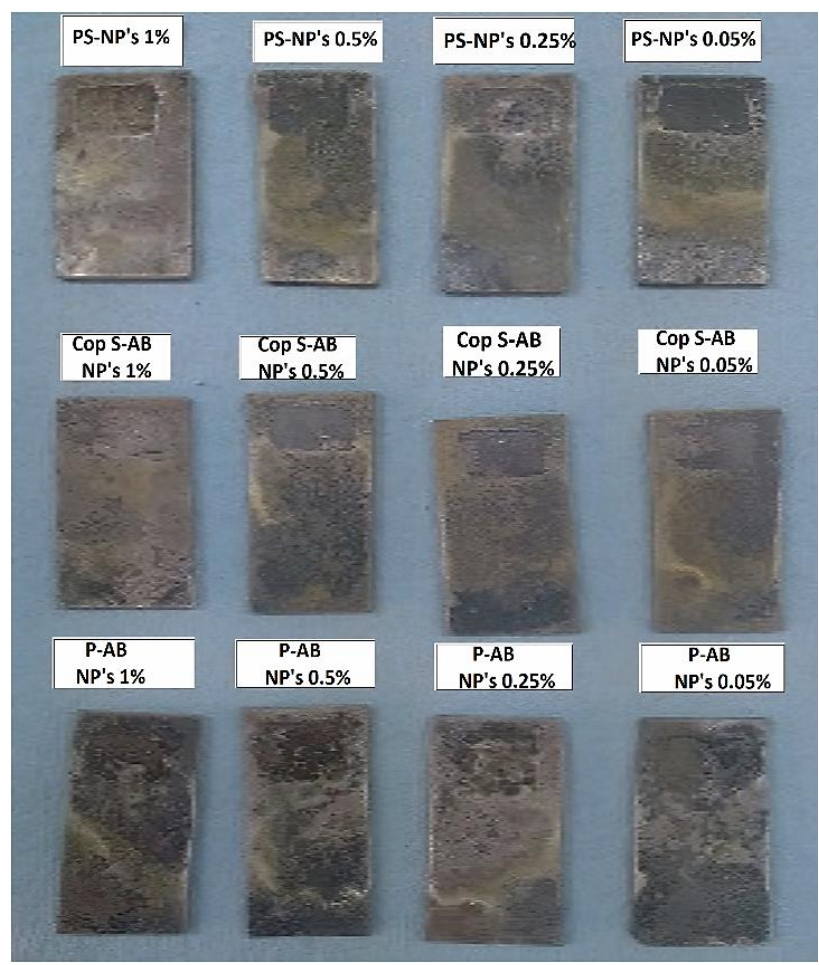

Figure 7 Nanocomposite of Magnetite-PS, Magnetite, Copolym, Magnetite-PBuA

Source: own work

Electrochemical impedance spectroscopy (EIS) measurements were performed with a traditional three-electrode cell using biologic potentiostate/galvanostate and EC-Lab software. 
A platinum electrode and saturated calomel electrodes (SCE) were used as auxiliary and reference electrodes, respectively. The working electrode was prepared from a carbon steel lamine $4 \mathrm{~cm}^{2}$ electroactive area.

With the percentages of lost weights, Nyquist diagrams were analyzed by impedance spectroscopy, highlighting the $0.05 \%$ ferrite copolymer and $0.05 \%$ magnetite copolymer composites as shown in Figure 7.

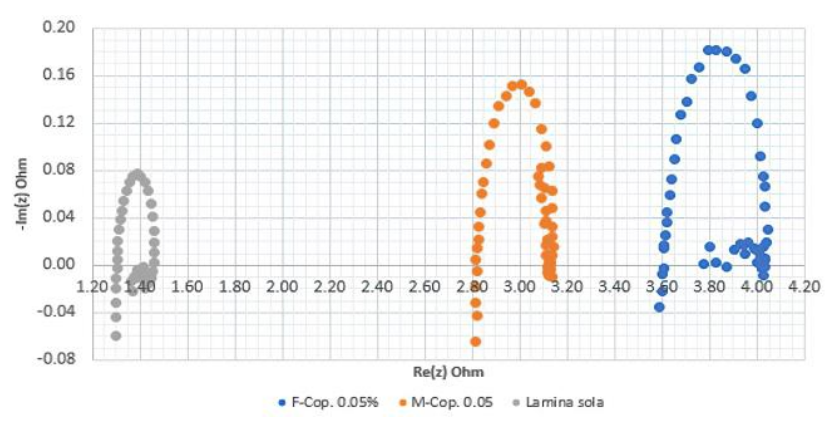

Figure 7 Impedance spectroscopy, reference uncoated steel sheet, Cop-Magnetite and Cop-Ferrite composite Source: own work [EC Lab and Excel]

So, the best nanocomposites produced were those with a PBuA/PS copolymer polymer matrix, with either reinforcement. Corrosion protection is better with copolymer composites at $0.05 \%$ magnetite and ferrite because increase the semicircle diameter. The diameter of the capacitive loop is approximately equal to the value of the charge-transfer resistance of the process of corrosion reaction and is associated with the corrosion resistance ability of the films in $\mathrm{H}_{2} \mathrm{SO}_{4}$ solution. Then the charge-transfer resistances of the modified electrodes are larger than that of the carbon steel electrode, which indicates that the self-assembled films can protect iron from corrosion

All EIS spectra can be analyzed and fitted with the equivalent circuit shown in Figure 8 , so obtain the double-layer capacitance $(\mathrm{Cdl})$, the frequency at which the imaginary component of the impedance is maximum.

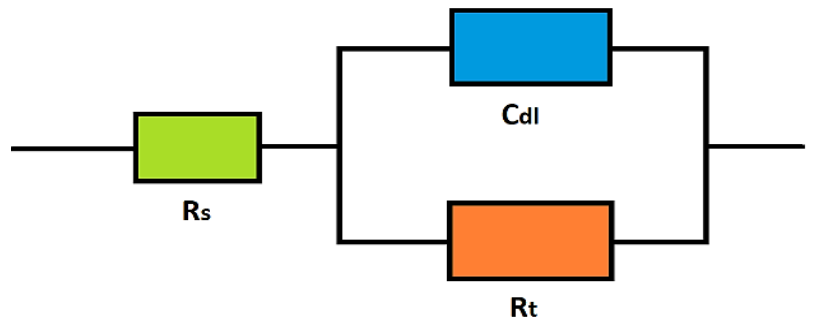

Figure $\mathbf{8}$ The equivalent circuit model for the electrochemical impedance measurements Source [2]

\section{Conclusions}

By means of the ultrasonic bath it is possible to obtain magnetic polymeric nanocomposites, with good stability for their applications. The stability and dispersion of polymeric nanocomposites depends on the molecular weight and viscosity of the polymer. At low viscosities, the nanoparticles disperse easily but are less stable than at high viscosities although dispersion requires more time.

\section{Acknowledgement}

The authors extend their appreciation to CIO Mexico to SEM analysis. And to project 144 of the call CIIC-UGTO-2020 (Obtaining polymeric nanocomposites via heterophase polymerization processes for the development of surface protection).

\section{References}

[1] Abdul-Ahad, P.G., \& Al-Madfai, S.H.F. (1989). Corrosion., 45, 978-980.

[2] Atta, A.M., El-Azabawy, O.E., Ismail, H.S., \& Hegazy, M.A. (2011). Corrosion Science, 53(5), 1680-1689.

[3] Costa, J.M., \& Liuch, J.M. (1984). Corrosion Sci., 24, 929-933.

[4] Gong, P.J., Yu, J.H., Sun, H.W., Hong, J., Zhao, S.F., Xu, D.M., \& Yao, S.D. (2006). J. Appl. Polym. Sci., 101, 1283-1289.

[5] Growcock, F.B. (1989). Corrosion., 45, 1003-1007.

[6] Growcock, F.B., Frenier, W.W., \& Andreozzi, P.A. (1989). Corrosion., 45, 1007-1015. 
[7] PeiJun, G., Wen, S.H., Jun, H., Mei, X.D., \& De, Y.S. (2007). China Ser. B-Chem., 50, 217-223.

[8] Sayos, R., González, M., \& Costa, J.M. (1986). Corros. Sci., 26, 927-934.

[9] Szabó, D., Czakó-Nagy, I., \& Zrínyi, M. (2000). J. Colloid Interface Sci., 221, 166172. 